\title{
Rivalrous Telecommunications Networks With and Without Mandatory Sharing
}

Thomas W. Hazlett

Follow this and additional works at: https://www.repository.law.indiana.edu/fclj

Part of the Administrative Law Commons, Antitrust and Trade Regulation Commons, Communications Law Commons, Internet Law Commons, and the Legislation Commons

\section{Recommended Citation}

Hazlett, Thomas W. (2006) "Rivalrous Telecommunications Networks With and Without Mandatory Sharing," Federal Communications Law Journal: Vol. 58 : Iss. 3 , Article 8.

Available at: https://www.repository.law.indiana.edu/fclj/vol58/iss3/8

This Symposium is brought to you for free and open access by the Law School Journals at Digital Repository @ Maurer Law. It has been accepted for inclusion in Federal Communications Law Journal by an authorized editor of Digital Repository @ Maurer Law. For more information, please contact rvaughan@indiana.edu.

\section{$\Psi$}

JEROME HALL LAW LIBRARY

INDIANA UNIVERSITY

Maurer School of Law
Bloomington 


\section{Rivalrous Telecommunications Networks With and Without Mandatory Sharing}

\section{Thomas W. Hazlett*}

I. INTRODUCTION 478

II. NETWORK SHARING RULES PURSUANT TO THE TELECOMMUNICATIONS ACT OF 1996 .................................... 483

III. TESTING THE “STEPPING STONE” THEORY .................................487

A. Growth in CLEC Lines.................................................... 487

B. Cable Telephony: The Dog That Didn't Bark...................... 489

IV. INVESTMENT AND NETWORK SHARING IN TELECOMMUNICATIONS MARKETS ...........................................491

A. Wireline Telecommunications Investment ........................... 491

B. Telecommunications Regulation and Investment Decline .... 494

C. Regulated Resale as a Business Model .................................497

D. Revealed Policy Preferences of Equipment Suppliers .......... 498

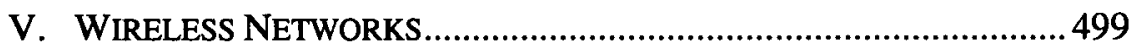

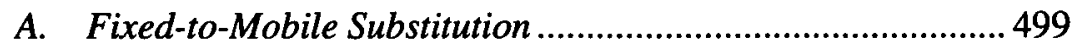

B. Spectrum Allocation........................................................ 500

C. State Regulation of Cell-Phone Rates................................... 505

D. Resellers in an Unregulated Market ..................................506

*This Essay extends research undertaken in THOMAS W. HAZLETT, COLEMAN Bazelon, John Rutledge, and Deborah Allen HewitT, U.S. Chamber of COMMERCE, SENDING THE RIGHT SIGNALS: PROMOTING COMPETITION THROUGH TELECOMMUNICATIONS REFORM (2004). The Author wishes to thank his coauthors in that project, as well as Arthur Havenner, Robert Hahn, Roberto Muñoz, and Robert Pindyck for valuable input into various topics germane to this Essay. 


\section{INTRODUCTION}

The 1996 Telecommunications Act ("1996 Act"), passed with bipartisan support, aimed to overturn the existing regime of regulated monopoly. Competition would be introduced, and regulation would fade away. Rival networks would then provide the consumer protection long delegated to state and federal agencies.

Elements of this strategy were cleanly implemented and have proven effective. These include two important policies to assist new network formation. The first was a federal preemption of state-issued franchise monopolies in local telecommunications. Most states had permitted but one operator, per area, to offer local phone service. In addition to other advantages, this measure instantly allowed 11,000 locally franchised cable TV operators to compete in a head-to-head rivalry with local exchange carriers ("LECs"). A second competitive strategy was an interconnection mandate, meaning that new networks would be able to exchange traffic with existing networks, thus facilitating entry. These rules enabled the emergence of hundreds of competitive local exchange carriers ("CLECs") in the aftermath of the 1996 Act.

The third strategy, however, has proven more problematic and will be the focus of this Essay. To assist the emergence of competition, the 1996 Act decreed that firms were to be given the opportunity to serve local phone customers without building physical network infrastructure, sharing the facilities owned by incumbent local exchange carriers ("ILECs"). If negotiations over wholesale rates proved unsuccessful, regulation would provide a solution. Competitive entrants would be offered each unbundled piece of existing phone networks (e.g., local loops and switching) at prices set by the government. Regulated wholesale access would be a stepping stone for new networks, which would then have the economic ability and incentive to construct new facilities of their own.

The object of this approach was not retail competition on the reseller model, which-with wholesale price controls-transferred fundamental economic planning from capital markets to governments. Rather, the aim was to create new physical networks by incentivizing infrastructure build-

1. See generally Thomas W. Hazlett, Economic and Political Consequences of the 1996 Telecommunications Act, 50 HASTINGS L.J. 1359 (1999) (detailing the economic consequences of the 1996 Act and the impact upon CLECs and cable companies); ROBERT W. Crandall \& Thomas W. Hazlett, Telecommunications Policy Reform in the United States and Canada, in TELECOMMUNiCATIONS LIBERALIZATION ON Two Sides OF THE ATLANTIC 8-38 (Martin Cave \& Robert W. Crandall, eds., 2001) (discussing the increased competition from CLECs after the 1996 Act). 
out. The 1996 Act was clear on this point, as federal courts have held, yet it downloaded sufficient transition management responsibility to the Federal Communications Commission ("FCC") and state public utility commissions for the policy to become conflicted. Regulators found their authority over price controls a tempting source of rent redistribution. Wholesale access terms were imposed to create retail competition by disrupting the crucial signals sent by retail customers to capital markets. The long-term adjustments prompted by nominal price reductions were largely external to the calculus of decisionmakers in this process, a nonmarket failure.

The central contradictions of the regime were manifested in the costs and benefits flowing from favorable resale terms offered CLECs to use the networks owned by ILECs. Terms making resale entry attractive simultaneously undercut incentives for entrants and incumbents to invest in fixed infrastructure. There is a theoretical argument that, while wholesale price regulation may induce some disinvestment in local telephone networks, this effect can be fully offset by strong economies of scope between retail service and infrastructure ownership. ${ }^{2}$ Given a quick and economical way to market services using the incumbent's network, the entrant is advantaged in ultimately creating its own. This prospect will, in turn, push incumbent network owners to invest in upgrades, as well. But this policy needle is difficult to thread.

Gerald Faulhaber has reviewed the historical experience of "policyinduced competition" in telecommunications. ${ }^{3}$ In some episodes, such as the opening of the phone equipment market, the mandate of a modular access point-typified by the now familiar telephone jack-worked to promote competition. The key was that the regulated border between the incumbent's network and the new rivals' interconnection was simple to define. It was a natural border.

In more complicated interfaces, however, results have been disappointing. Faulhaber classifies the post-1996 Act unbundling rules as intensely complex, artificial, and not likely to succeed. Richard Epstein sees economic incentives as exacerbating the informational requirements stressed by Faulhaber. ${ }^{4}$ The incentives for cooperation achieved in contracts are absent when regulators imposed forced marriage on ILECs

2. See Thomas W. Hazlett \& Arthur M. Havenner, The Arbitrage Mirage: Regulated Access Prices with Free Entry in Local Telecommunications Markets, 2 REV. OF NETWORK ECON. 440, 441 (2003).

3. See generally Gerald R. Faulhaber, Policy-Induced Competition: The Telecommunications Experiments, 15 INFO. ECON. \& POL'Y 73 (2003).

4. Richard A. Epstein, Takings, Commons, and Associations: Why the Telecommunications Act of 1996 Misfired, 22 YALE J. ON REG. 315, 315 (2005). 


\section{and CLECs.}

Alfred Kahn sees political actors engaging in the rent seeking game that ensues. ${ }^{5}$ By creating mechanisms to redistribute income within the industry, political coalitions form to claim the rents at stake. Firms are rewarded for political support when rules are adjusted in their favor, and firms targeted for potential appropriation find it profit maximizing to increase their political investments for defensive purposes. This results in higher returns to those who influence the regulatory process. ${ }^{6}$

The evidence from telecommunications markets supports the view that mandatory network sharing has effectively blocked the transition it was advanced to assist. Conversely, the transition to competitive networks anticipated in the 1996 Act has been largely achieved, albeit through the development of alternative telecommunications systems not aided by mandatory network sharing rules. Competition has proceeded outside in, not inside out. The emergence of what Faulhaber calls "category killers" is now facilitating a transition to competition in local telephony.

These marketplace alternatives have been delayed by distractions and impediments erected under policy-induced competition. Hence, the legal collapse of that regime is welcome in the marketplace. Of key significance is the March 2, 2004, opinion rendered in the case of United States Telephone Association v. Federal Communications Commission (USTA II), ${ }^{7}$ which-with the June 9,2004 , decision of the FCC not to appeal that

5. Alfred Kahn, Letting Go: Deregulating the Process of Deregulation or TEMPtation OF THE KLEPTOCRATS AND THE POLITICAL ECONOMY OF Regulatory DisingenUOUSNESS (1998); ALFRED E. KAHN, LESSONS FROM DEREGULATION: Telecommunications and Airlines After the Crunch (2004). See also Alfred E. Kahn, Timothy J. Tardiff \& Dennis L. Weisman, The Telecommunications Act at Three Years: An Economic Evaluation of Its Implementation by the Federal Communications Commission, 7 INFO. ECON. \& POL'Y 319 (1999).

6. See Fred S. McChesney, Money for Nothing: Politicians, Rent Extraction, AND POLITICAL EXTORTION (1997).

7. The ruling making sequence is as follows: Local Competition Provisions in the Telecommunications Act of 1996, First Report and Order, 11 F.C.C.R. 15499 (1996), rev'd in part, aff'd in part, 120 F.3d 753 (8th Cir. 1997), rev'd in part, aff'd in part, 525 U.S. 366 (1999); Implementation of the Local Competition Provisions of the Telecommunications Act of 1996, Third Report and Order and Fourth Further Notice of Proposed Rulemaking, 15 F.C.C.R. 3696 (1999); Implementation of the Local Competition Provisions of the Telecommunications Act of 1996, Supplemental Order, 15 F.C.C.R. 1760 (1999); Implementation of the Local Competition Provisions of the Telecommunications Act of 1996, Fourth Report and Order in CC Docket No. 96-98, 14 F.C.C.R. 20912 (1999); Iowa Util. Bd. v. FCC, 219 F.3d 744 (8th Cir. 2000); Implementation of the Local Competition Provisions of the Telecommunications Act of 1996, Supplemental Order Clarification, 15 F.C.C.R. 9587 (2000), aff'd sub nom., 309 F.3d 8 (D.C. Cir. 2002); Implementation of the Local Competition Provisions of the Telecommunications Act of 1996, Notice of Proposed Rulemaking, 16 F.C.C.R. 22781 (2001); Verizon Comm., Inc., v. FCC, 535 U.S. 467 (2002); U.S. Telecomm. Ass'n v. FCC (USTA I), 290 F.3d 415 (D.C. Cir. 2002); U.S. Telecomm. 
opinion to the U.S. Supreme Court ${ }^{8}$-overturned essentially the entire regime for unbundled network elements ("UNEs").

This Essay reviews evidence yielded by a series of natural experiments that permit evaluation of comparative institutional mechanisms for encouraging telecommunications competition. First, the pattern of entry by CLECs is examined. These data suggest that resale competition achieved via unbundling regulation does not lead to additional facilities-based entry, but tends to displace such activity. Deployment of cable telephony, for instance, slowed just as unbundled network elementsplatform ("UNE-P") line growth accelerated, and then accelerated with the collapse of the UNE-P regime. Second, according to the stepping stone theory, capital expenditures by networks are predicted to rise with unbundling. In fact, investment flows fall dramatically in the sector for both incumbents and entrants as network sharing increases. This pattern cannot be explained solely by the business cycle, as it is distinct from that observed in adjacent markets where different sharing rules apply.

Third, alternative policy regimes suggest that competition is viable in the absence of mandatory network sharing. In residential broadband, the least regulated medium, cable modem service, has consistently outperformed its direct rival-digital subscriber line ("DSL") serviceprovided via local exchange carrier networks. When DSL service was partly deregulated in early 2003 , however, the broadband race markedly intensified. DSL penetration increased in absolute terms and relative to cable growth, an outcome inconsistent with the view that network-sharing mandates promote investment or deployment.

In wireless phone markets, competitive entry proved highly effective once personal communications service ("PCS") operators were licensed, beginning in 1995. Nominal retail prices fell approximately $79 \%$ in the 1993-2002 period (from $\$ 0.57$ per minute to $\$ 0.12$ ) with minutes of use rising $3158 \%$ (from 19 billion minutes to 619 billion). ${ }^{9}$ State rate regulation

Ass'n v. FCC (USTA II), 359 F.3d 554 (D.C. Cir. 2004).

8. Ben Charny, Bush Administration Won't Appeal Phone Decision, CNET NEws.COM, June 9, 2004, http://news.com.com/Bush+administratio+won't+appeal+phone+ decision/2100-1037_3-5229698.html.

9. See Implementation of the Local Competition Provisions of the Telecommunications Act of 1996, Fourth Report and Order in CC Docket No. 96-98, 14 F.C.C.R. 20912 (1999); Iowa Util. Bd. v. FCC, 219 F.3d 744 (8th Cir. 2000); Implementation of the Local Competition Provisions of the Telecommunications Act of 1996, Supplemental Order Clarification, 15 F.C.C.R. 9587 (2000), aff'd sub nom., 309 F.3d 8 (D.C. Cir. 2002); Implementation of the Local Competition Provisions of the Telecommunications Act of 1996, Notice of Proposed Rulemaking, 16 F.C.C.R. 22781 (2001); Verizon Comm., Inc., v. FCC, 535 U.S. 467 (2002); U.S. Telecomm. Ass'n v. FCC (USTA I), 290 F.3d 415 (D.C. Cir. 2002); U.S. Telecomm. Ass'n v. FCC (USTA II), 359 
was preempted in August 1994, allowing comparison between competing regimes. Cellular rates did not exhibit a post-deregulation "fly-up," showing that the rate control scheme-which included wholesale prices to facilitate reseller competition in retail markets-was ineffective. When PCS entry occurred, however, rates fell dramatically, both absolutely and relative to trend, providing further evidence of the effectiveness of facilities-based competition. The emergence of competitive wireless networks also reveals how market institutions naturally arise, as the resale model, having proven difficult to effectively implement via regulation in fixed or wireless networks, now flourishes in mobile phone markets with such national "carriers" as TracFone or Virgin Mobile.

Of direct significance for local telephone regulation is that competing facilities are in place. Cable TV systems pass about ninety-nine percent of U.S. households ${ }^{10}$ and can economically supply either circuit-switched or Voice over Internet Protocol ("VoIP") telephony. 11 In addition to this headto-head fixed line rivalry, plain old telephone service ("POTS") faces competition from at least four national wireless networks. ${ }^{12}$ Substantial migration has already taken place, with wireline long distance calls sharply declining as wireless carriers offer subscribers "buckets" of domestic anywhere minutes.

Since June 2004, the emergence of facilities-based competition has intensified. Cable operators and ILECs have stepped up "triple play" offerings of voice, video, and high-speed data; phone carriers have invested more aggressively in fiber to the home allowing delivery (without direct broadcast satellite ("DBS") of the triple play menu; cable operators, now embracing VoIP, serve about 5,000,000 telephone customers, while independent VoIP supplier Vonage has over 1.3 subscribers. $^{13}$

F.3d 554 (D.C. Cir. 2004). Ben Charny, Bush Administration Won't Appeal Phone Decision, CNET NEwS.COM, June 9, 2004, http://news.com/Bush+administration+won't+appeal+ phone+decision/2100-1037_3-5229698.html. See CELlULAR TELECOMM. \& INTERNET Ass'N, SEMIANNUAL Data SuRvey ReSUlts (2005), http://files.ctia.org/pdf/CTIAEndYear 2005Survey.pdf.

10. See Nat'l Cable \& Telecomm. Ass'n, Industry Overview, http://www.ncta.com/ Docs/PageContent.cfm?pageID=86 (last visited Apr. 7, 2006). Statistic is reported as an estimate for 2006.

11. Cox Communications, Whitepaper: Voice over Internet Protocol: Ready for Prime Time 2 (May 2004), http://media.corporate-ir.net/media_files/IROL/76/76341/May_ whitepaper_2.pdf. Cox, the cable company that has most aggressively deployed telephony, estimates that per phone subscriber capital costs for VoIP have fallen to under $\$ 300$, compared to just over $\$ 500$ for traditional circuit-switched voice service. Id. at 11 .

12. The four national networks consist of Cingular (having acquired AT\&T Wireless), Verizon Wireless, Sprint (having acquired Nextel), and T-Mobile.

13. Peter Grant, Cable-TV Companies Hold Great Expectations, WaLl ST. J., Apr. 25, 2006 , at $\mathrm{C} 1$. 
These developments suggest that recent deregulatory changes are proconsumer. But they also support the view that policy makers can do much more to assist the creation of competitive options both by continuing to trim the regulatory obligations of network owners and by increasing the availability of radio spectrum. As shown below, the artificial scarcity imposed by federal regulators in wireless markets is now the overwhelming obstacle to both enhanced competition and telecommunications network development.

\section{NETWORK SHARING RULES PURSUANT TO THE TELECOMMUNICATIONS ACT}

The vision of the 1996 Act was that the traditional model of regulated monopoly was obsolete and that public policy should switch strategies to accommodate the advent of competitive networks. The 1996 Act thus terminated a long march. Where the 1950 s had seen an end-to-end telephone monopoly oppose use of any foreign equipment, including the Hush-a-Phone attachment (a rubber cup ${ }^{14}$ that, fastened onto a handset, allowed a caller to speak without being heard in the next cubicle), micromanaged markets ultimately proved deficient. Joe Farrell, the FCC's chief economist in 1996, explained:

[T]elephone regulation, like the tax code, has grown unwieldy, unmanageable, inefficient, and dysfunctional. It's time to find an alternative. Competition is the greatest technique ever invented to bring about innovation, low prices, choice, and efficiency. If we can efficiently create competition in this so-called natural monopoly, we'll have done a great thing. ${ }^{15}$

As the passage notes, the policy strategy was not to simply convert assumptions, but to actively create competitive rivalry in the last mile. This is where end users connect to phone networks. To help new service providers get going, network sharing rules were imposed. Entrants could piggy-back on incumbents' connections, reselling service. This could be done either in a total service resale ("TSR") package, with the competitor retailing phone service delivered entirely over the incumbent's network, or the entrant could use just part of the existing network, unbundling ILEC facilities such as the local loop. Mandatory network sharing would be a stepping stone that would assist rivals building new networks.

Sharing rules would be rendered moot, however, if prices, or other terms of use, were set so as to discourage entry. Hence, rate regulation was established for wholesale network access. TSR prices were based on the

14. Joseph Farrell, Creating Local Competition, 49 FED. COMM. L.J. 201, 206 (1996), available at http://www.law.indiana.edu/fclj/pubs/v49/nol/farrell.html.

15. Id. at 202. 
regulated retail price of service minus the avoided costs of the incumbent carrier-cost savings from having another firm provide marketing and customer service-generally yielding entrants discounts from retail prices of $15-25 \% .^{16}$

The pricing of UNEs involved more complex rules, pursuant to FCC decisions in the aftermath of the 1996 Act. First, regulators decided which pieces of the network were to be offered separately. Then regulators set prices for each UNE. The framework adopted by the FCC used the theoretical costs of an ideally efficient new network, a model known as total element long-run incremental cost ("TELRIC"). ${ }^{17}$ Because existing networks are built with older technology and may not be optimally configured given changing demand and supply conditions, wholesale prices are set below an incumbent's actual costs under TELRIC rates. ${ }^{18}$

The original idea of unbundling was that the entrant would want to purchase elements of the incumbent's network to combine with other elements it would provide, overcoming barriers to entry. The FCC, however, ended up creating a package that offered all unbundled network elements in a program called unbundled network elements-platform ("UNE-P"). Alfred Kahn notes the contradiction in terms, which references reassembly of the parts regulators disassembled in order to assist competitive entry. ${ }^{19}$ The policy was important, however, because it typically offered prices far below TSR. Analysts estimated that the average discount for wholesale access under UNE-P (from retail prices) reached about fifty percent in 2003 . $^{20}$

The decision by the government to offer relatively low prices for

16. UBS Warburg, How Much Pain From UNE-P? 6 (2002), http://files.cwaunion.org/National/CommunicationsPolicy/Other/ubs_analysis.pdf.

17. Alfred Kahn underscores the key point in his colorful depiction of the rule as "TELRIC-BS." The appended acronym is said to stand for "blank slate," which captures perhaps the key pricing element: costs are determined by regulators to be what a most efficient network would incur if built today. Since prices are periodically reset and costs, driven by technological advance, tend to fall over time in telecommunications networks, this means that network owners will predictably recoup less than the costs they incur when the facilities they create are rented in future periods. KAHN (1998), supra note 5. See also Robert Pindyck, Mandatory Unbundling and Irreversible Investment in Telecom Networks (Nat'l Bureau of Econ. Research, Working Paper No. 10287, 2004), available at http://papers.nber.org/papers.w10287.pdf.

18. "[I]t appears to have been common ground that, because of ongoing technological improvement (among other things), prices so determined would fall well below the costs the ILECs had actually historically incurred in constructing the elements." USTA II, 359 F.3d at 562.

19. KAHN (2004), supra note 5, at 23.

20. The Far-Reaching Impact of UNE-P Regulation, MOODY's INVESTORS SERVICE 5 (Oct. 2003) (on file with Author). 
wholesale access was based on the belief that competitive entry would be encouraged. ${ }^{21}$ Low wholesale prices can do that, but they simultaneously discourage other entry, as well as discourage capacity expansion or quality upgrades by incumbents. Marketplace results will be reviewed below. One clear outcome is that the rule-setting process has proven extremely quarrelsome, with substantial public and private resources diverted from productive enterprise. Said one analyst: "You have a total Hatfield and McCoy feud. This is an eight-year, claw-your-opponent's-eye-out battle regulatorily, legally and politically. If they could have settled this, they would have, a long time ago."22

The Circuit Court of Appeals for the District of Columbia overturned, for the third time, the FCC's unbundling rules in March $2004 .{ }^{23}$ When the Bush Administration and the FCC decided not to appeal this ruling to the U.S. Supreme Court in June 2004, a new policy was at hand. Quickly, both leading CLECs-AT\&T and $\mathrm{MCI}$-made plans to suspend their resale offerings. $^{24}$

But the retreat from regulation did not spell the end of competition or even an unambiguous economic victory for the Bell Companies, the owners of the leading ILEC networks. As CLECs abandoned UNE-P they simultaneously embraced emerging networks. According to one trade publication: "AT\&T Corp., the most visible of the UNE-P resellers, has been ... signaling its strategy by pulling out of numerous markets, rolling out VoIP and striking wholesale deals with competitive LECs .... AT\&T[']s migration to competitive facilities is mirrored by other UNE-P providers." 25

Covad, a data services provider that rents incumbents' local loops to deliver DSL service, joined the Intel-led WiMax Coalition developing wireless broadband networks. "WiMAX lets providers bypass phone

21. The argument has been made that it is efficient to mandate prices that allow incumbent network owners to recover only their marginal costs or such costs plus some allowance for common costs without reference to the sunk costs of creating the network infrastructure. This confuses the profit maximizing behavior of a firm over short-term intervals with the conditions necessary to stimulate the optimal level of investment over time. See Pindyck, supra note 17, at 9, 11-12 (quotation marks omitted).

22. Ellen Simon, Phone Competition Dials up a Battle Royal, Wash. Post, May 21, 2004, available at http://www.freepress.net/news/print.php?id=3609 (citation omitted).

23. See USTA II, 359 F.3d at 554.

24. See Almar Latour \& Shawn Young, Rules Change Could Alter the Fate of LongDistance Giants, WALL ST. J., June 11, 2004, at B1, B3.

25. Khali Henderson, UNE-P Resellers: It's Your Move, PHONE+, Aug. 2004, http://www.phoneplusmag.com/articles/481 resell01.html. AT\&T claimed the move was "a major step moving away from dependence on the Bells' UNE-P to facilities-based competition." Susan Polyakova, AT\&T To Move to UNE-L if Regulatory Clarity is Ensured, COMM. DAILY, July 8, 2004, at 1 (citation omitted). 
companies for the 'last mile' connections to homes and businesses." ${ }^{\text {,26 }}$ The transition to wireless is reported thusly:

Covad has relied on traditional copper lines leased from the Bells for its DSL service, using access that has been mandated for years. . . But the Federal Communications Commission is phasing in regulations that will not require the Bells to share new lines with outside companies.

Fearing that the Bells will charge exorbitant rates or refuse to share lines altogether, Covad and other companies that resell Internet access are looking for alternative technologies for their wholesale broadband. EarthLink has already made initial forays into the wireless market, recently launching a service with Digitalpath in Northern California. ${ }^{27}$

The EarthLink venture has since expanded via a new partnership with Korea's SK Telecom. Using network capacity of Verizon Wireless and Sprint PCS, EarthLink now offers high-speed (i.e., Code-Division Multiple Access ("CDMA") Evolution-Data Optimized ("EV-DO") wireless services, targeting early adopters of advanced applications. The foray, branded as Helio, is premised on unregulated wholesale access to CDMA networks using the MVNO model. ${ }^{28}$

The consensus emerged that, despite the decline of UNE-P, "wireless and VoIP services, including over cable, will likely provide increasing competition." 29 Revealingly, the lapse of unbundling obligations was not met with visible investor enthusiasm for Bell company shares. ${ }^{30}$ This was no surprise to analysts who have largely touted the theme: "Bell Legal Victory: Winning the Battle, but Losing the War." ${ }^{31}$ They conclude that the

26. Bill Wolfe, New Long-Range Standard May Heat Up Wireless Internet, THE COURIER-J., Feb. 22, 2004, at E1.

27. Jim Hu, Cable, DSL face threats, CNET NEws.COM, July 29, 2004, http://news.com.com/Broadband+Cable\%2C+DSL+face+threats/2009-1034_3-5261385. html.

28. Matthew Maier, Sky Dayton Goes Cellular, Business 2.0, Feb. 1, 2005, http://www.helio.com/headlines/sk_020105.pdf. CDMA is the code division multiple access algorithm used to deliver advanced voice and data services, and is the basic technology used in the U.S. by Verizon Wireless and Sprint. MVNOs are mobile virtual network operators that provide retail wireless service by purchasing minutes in bulk from owners of physical networks.

29. Legg Mason, Bells on Roll, but FCC Fights Affect Speed, Scope of Wholesale/UNE Relief, MEMORAndum, June 30, 2004, at 1 (on file with the Author).

30. Between June 9 when the Administration announced it would not appeal the D.C. Circuit Court of Appeals opinion to the U.S. Supreme Court, and June 15 when the UNE rules were allowed to lapse (the U.S. Supreme Court turned down a stay the preceding day) the legal battle to save the existing UNE rules was lost. Share prices of the three large-cap Bell Operating Companies-BellSouth, SBC, and Verizon-from the opening on June 1 to close on June 21 , a period framing the regulatory period, reveals virtually no movement relative to the S\&P 500 Index. Equally weighted returns, relative to the market, were $0.13 \%$ for the three companies over the three week period.

31. Precursor GrP., Bell Legal Victory: Winning the Battle, But losing the 
incumbents' legacy networks are better off with fewer unbundling obligations, but that the regulatory relief is "too little, too late, and technology has replaced regulation as the main driver of the competitive threat to the Bells." 32

\section{TESTING THE “STEPPING STONE” THEORY}

\section{A. Growth in CLEC Lines}

In commenting on the Supreme Court's May 2002 decision $^{33}$ to uphold the use of TELRIC in pricing wholesale access, Greg Rosston and Roger Noll wrote:

[T] he decision permits a test of whether the stepping stone theory of local access entry is valid. While the outcome of this experiment is uncertain, two possible outcomes are likely to be good for consumers. One is that facilities-based competition in wire-line access, with entrants eventually providing switching and other intelligent network functions, emerges from UNE-based entrants. The second is that wireless services make local telephone access competitive even if wire-line competition remains very limited. In either case, local access regulation can be replaced by competition.

The third possible outcome is that when the dust settles, most local access competition will take the form [of] resale of the incumbent's facilities. In this case, consumers are not likely to benefit, and regulation will, if anything, grow as regulators are called upon to resolve disputes between incumbents and resellers.

The results of this empirical test are now available. The pattern exhibited by the growth of CLEC lines is seen in Figure $1 .^{35}$ UNE-P lines were numerically insignificant until 1999 . At that point, UNE-P lines were dominated by TSR and CLEC-owned lines. With regulatory changes associated with the 271 certification process, ${ }^{36}$ the growth in such lines was

War, Precursor Telecom \& Media Research (June 18, 2004) (on file with the Author).

32. Id.

33. Verizon Comm., Inc. v. FCC, 535 U.S. 467 (2002).

34. Gregory L. Rosston \& Roger G. Noll, The Economics of the Supreme Court's Decision on Forward Looking Costs, 1 REV. OF NETWORK ECON. 81, 88-89 (2002).

35. See Ind. Analysis \& TeCh. Div., FCC, Local Telephone Competition: Status AS OF JUNE 30, 20041 (2004), available at http://www.fcc.gov/Bureaus/Common_Carrier/ Reports/FCC-State_Link/IAD/lcom0604.pdf.

36. In the 1996 Act, Bell companies were permitted to offer long-distance service in their local service territories once they satisfied regulators that their local markets were open to competition. Political compromises were eventually reached that included substantially more favorable terms and conditions for UNE access, resulting in the rapid increase in the use of such lines by CLECs. The first Section 271 certification granted was to Verizon's petition in New York in December 1999, the second was to SBC's petition in Texas in June 2000. The process was completed for all other states in 2004. 
rapid. As this growth accelerated, growth in facilities-based, or CLECowned, lines does not follow, but appears to slow. By 2004, there were about 29 million CLEC lines compared to about 152 million ILEC lines, ${ }^{37}$ of which:

Fig. 1. CleC Lines by Type

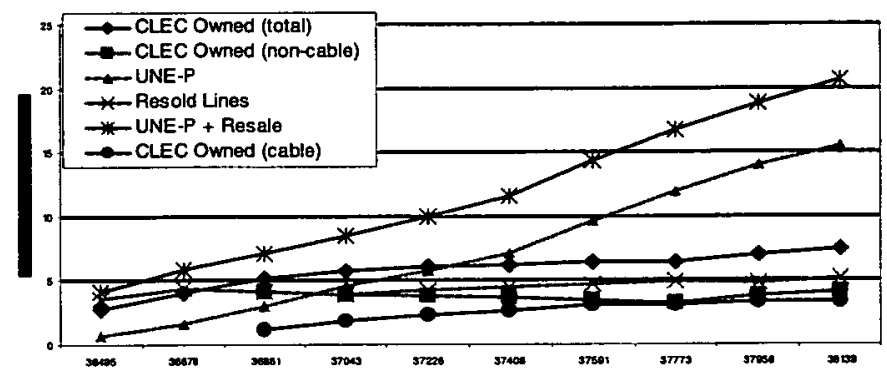

- 16 million were UNE-P

-2 million were TSR

-7 million were provided over competitive networks, including about three million cable telephone lines

-4 million used ILEC local loops but otherwise used the facilities (e.g., switches and transport) of the CLEC, an approach called "UNEL.",38

Hence, UNE-P lines quickly came to dominate CLEC lines. Moreover, as UNE-P lines increased, growth in facilities-based entry did not accelerate, but flattened. As UNE-P lines grew over 300\% in the 2000 to mid-2003 period, facilities-based competitive lines grew just twenty percent-a substantial slowing of the trend. The number of facilities-based, noncable lines decreased from 4.1 million at the end of 2000 to 3.2 million by mid-2003. The correlation between UNE-P lines and non cable facilities-based lines is almost a perfect -1 (-.99685), meaning that UNE-P line growth has been accompanied by a simultaneous reduction in facilities-based competitive lines period by period.

In econometric tests, the level of UNE-P subscribership in one period does not help predict the level of facilities-based competitive subscribership in the next period. Rather than provide a stepping stone to new entry, the UNE-P regulatory offering appears to crowd out new

37. Ind. Analysis \& TeCh. Div., FCC, Federal Communications Commission RELEASES DATA ON LOCAL TELEPHONE COMPETITION 1 (2004).

38. Patrick Brogan \& Scott Cleland, Facilities-Based CLECs Benefit from Migration Away from UNE-P, PRECURSOR BULLETIN, July 7, 2004 (on file with the Author). 
networks. The proportion of UNEs accounted for by UNE-P increases from about one-third in 1999 to about four-fifths in 2004.

\section{B. Cable Telephony: The Dog That Didn't Bark}

Were the 1996 Act to encourage development of competitive phone networks, the entry path provided by cable TV system expansion would appear to be the obvious place to begin. National cable TV infrastructure was in place prior to the 1996 Act, and the costs for upgrading that infrastructure to provide voice telephony comparable to that provided by LECs was modest. As calculated by Cox Cable, the incremental cost of an average phone subscriber was about $\$ 527$ in 2003 and featured a payback period of just three years based on conservative demand assumptions. 39

Indeed, cable operators aggressively expanded their service menus to include high-speed Internet access in the late 1990s and quickly became the dominant providers of broadband access in residential markets, passing over 107 million households (of about 110 million households) and garnering over 24 million subscribers as of December 2005 . $^{40}$ Yet, cable phone service has lagged far behind. Despite serving more than 2 million subscribers in 2001, cable telephony growth slowed to a crawl in 20022003. (See Figure 2.) Not only did cable operators decide not to pursue telephone subscribers as aggressively as they sought broadband customers, they actively chose to pull back from this market. ${ }^{4}$

Renewed cable industry enthusiasm for phone service, however, was evident in 2004. As the network sharing regulation regime collapsed, several cable companies-often in partnership with CLECs-announced that they were deploying new VoIP offerings. By year-end 2004, VoIP subscribership reached 1 million, up from 130,000 at year-end 2003, half of which was attributed to cable TV operators. ${ }^{42}$ In 2005 , cable telephone households increased by $1,928,400$ - well over ten times 2003's growth of $156,000 .^{43}$ Cable telephone service is increasingly available to customers,

39. Whitepaper, supra note 11 , at 11 .

40. LEICHTMAN RESEARCH GRP., RESEARCH NOTES 8 (1Q 2006), http://www.leitchtman research.com/research/notes03_2006.pdf [hereinafter LEICHTMAN 2006].

41. The industry leaders in phone service had been AT\&T and Cox. When Comcast acquired AT\&T's cable assets in 2002, it announced that it was suspending marketing efforts aimed at new subscribers, leaving Cox virtually alone in pursuit of cable phone customers.

42. As of year-end 2004, Yankee Group estimated that 1 million Americans subscribed to VoIP service, of which 500,000 subscribed to VoIP delivered by their cable operator. ZDNet, IT Facts, 1 Mln U.S. VoIP Subscribers by Year-End 2004, http://www.itfacts.biz/ index.php?id=P1453 (last visited Mar. 22, 2006).

43. LEICHTMAN RESEARCH GRP. supra note 41, at 7; LEICHTMAN RESEARCH GRP., RESEARCH NOTES 8 (1Q 2004) (on file with the Author) [hereinafter LEICHTMAN 2004]. 
and the existence of a wireline substitute drives improvements in the price and quality of LEC-supplied voice service. Cable TV systems offered just $16 \%$ of U.S. households phone service at year-end 2003, but this increased to one-half of U.S. households by year-end 2005 . $^{44}$

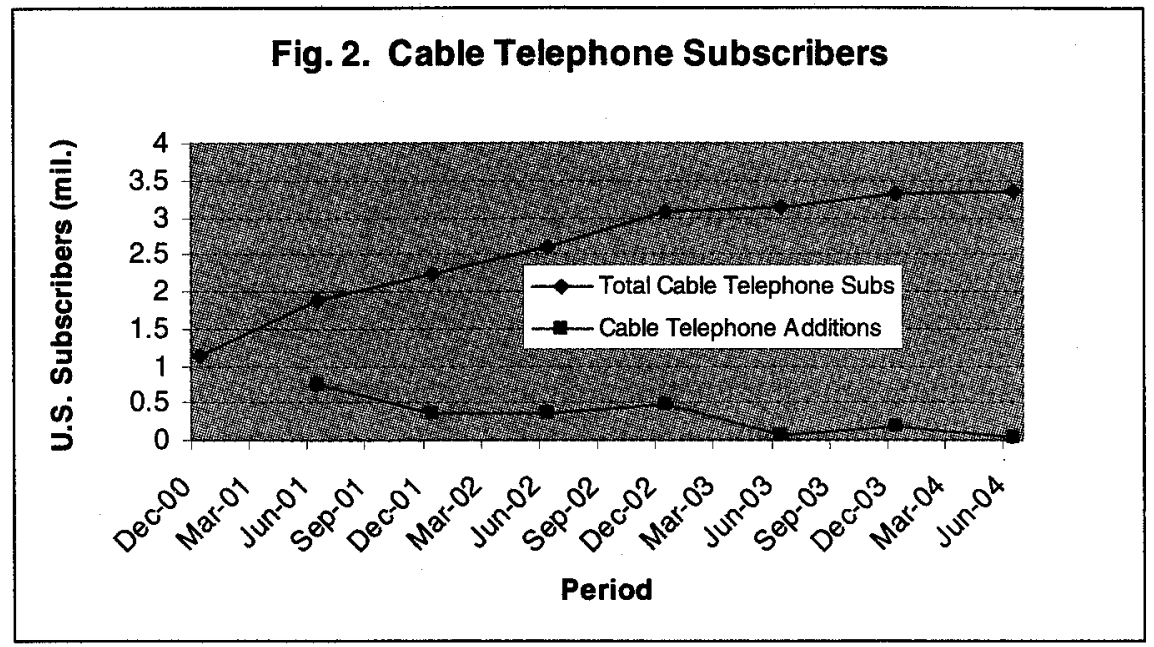

Source: Ind. ANAlysis \& TECh. DIV., FCC, Local Telephone COMPETITION: STATUS AS OF JUNE 30, 20041 (2004).

The demise of the network sharing regime was coincident with the emergence of VoIP, which was long anticipated as a substitute for POTS. ${ }^{45}$ With UNE-P resale expanding, cable networks reduced their own exposure to rent appropriation by delaying investment in telephony. This economized on certain irreversible investments, eliminating risks associated with competing in a market where rivals' input costs may be adjusted up or down according to political decisions. In April 2004, a broadband industry analyst saw the conundrum thusly:

The crux of the problem for cable is this. Thanks to UNE-P regulations and the entrance of U.S. long distance companies into local telephony, lifeline plain old telephone service (POTS) is already a commodity. . . .

AT\&T, Sprint, and MCI are now all selling their own unlimited local and long-distance consumer POTS service bundles for under $\$ 50$ a month (taxes excluded). These plans, like AT\&T One Rate USA, The Neighborhood by MCI and Sprint Complete Sense, often include value-added features like voicemail, caller ID, call waiting and threeway calling. For the low end of the market, they offer even simpler bundles for under $\$ 30$ per month. One has to wonder: Why would most

44. LEICHTMAN 2004, supra note 43; LEICHTMAN 2006, supra note 41.

45. See, e.g., Eric J. Savitz, 'Net Threat: Internet Telephony Promises to Send Some Conventional Phone Businesses Packing, BARRON's, Oct. 13, 1997, at 37. 
mainstream consumers risk going to cable IP phone service when they

can switch to AT\&T for a package that is cost-comparable[?] $]^{46}$

But just as this question was being posed, the UNE-P regime collapsed. The virtually instantaneous combustion of VoIP, strongly aided by cable TV operators, suggests that the network sharing mandates exerted a strongly negative effect on telecommunications investment incentives. This expectation was explicitly voiced by market analysts. ${ }^{47}$

\section{INVESTMENT AND NETWORK SHARING IN TELECOMMUNICATIONS MARKETS}

\section{A. Wireline Telecommunications Investment}

Investment in local telecommunications networks declined precipitously in the period coincident with the implementation of extensive network sharing, as measured by the increase in UNE-P lines. The incidence and effects of this investment decline were widely noted by analysts. ${ }^{48}$ The key policy issue is whether the entire decline can be attributed to cyclical factors specific not to telecommunications regulation but to the post-bubble stock market crash. Investment patterns reveal that, while capital spending generally deteriorated throughout the sector, declines were notably severe among CLECs and ILECs. This relatively poor performance occurred as network sharing mandates facilitated competitive entry via resale, the ostensible trigger for additional investments by incumbents and entrants alike under the stepping stone theory.

46. Michael Harris, Cable's IP Telephony Conundrum, CABle Datacom News, Apr. 1, 2004, www.cabledatacomnews.com/apr04/apr04-2.html.

47. Fulcrum Global Partners Wireline Communications: REVISING BLS AND SBC ESTIMATES DUE TO AWE DILUTION 2 (Mar. 10, 2004).

We believe UNE-P demise could accelerate broadband deployment-with the potential elimination of UNE-P resale, we believe the spread of broadband could accelerate, as companies would not be as concerned with the loss of telephony subscribers to such companies that do not have to invest in ANY infrastructure. Simply put, where UNE-P is successful, cable telephony has not been. Such a move to eliminate UNE-P would further the FCC's primary objective of near ubiquitous nationwide broadband deployment, in our opinion.

Id. (emphasis in original) (on file with the Author).

48. See, e.g., Soundview TeCh. GrP, Wireline Communications Services: Sector CaPITAl EXPEndTuRE UPDATE (May 1, 2003) (on file with the Author); J. Parmelee, Telecom Equipment-Wireline Update, CREDIT SuISSE FIRST Boston, Sept. 26, 2002 (on file with the Author); Fulcrum Global Partners, Wireline Communications: THOUGHTS ON FCC ORDER (Feb. 25, 2003) (on file with the Author); PRECURSOR GRP., Wireline Telecom CaPeX Gumance Is Likely Too Optimistic (Aug. 8, 2003) (on file with the Author). 
The flow of capital investment by local telecommunications entrants reached a high in 2000 , then declined $85 \%$ by $2003 .^{49}$ (See Figure 3.) This effectively means that the entire value of capital investment undertaken through 2002 - at least $\$ 72$ billion-was eliminated, as the market value of the entire CLEC sector was only about $\$ 4$ billion in 2003 , or approximately the level of 2003 capital investment. ${ }^{50}$ This level of disinvestment is inconsistent with the stepping stone theory, and additionally suggests that the business model of resale at regulated wholesale rates proved financially unsustainable. $^{51}$

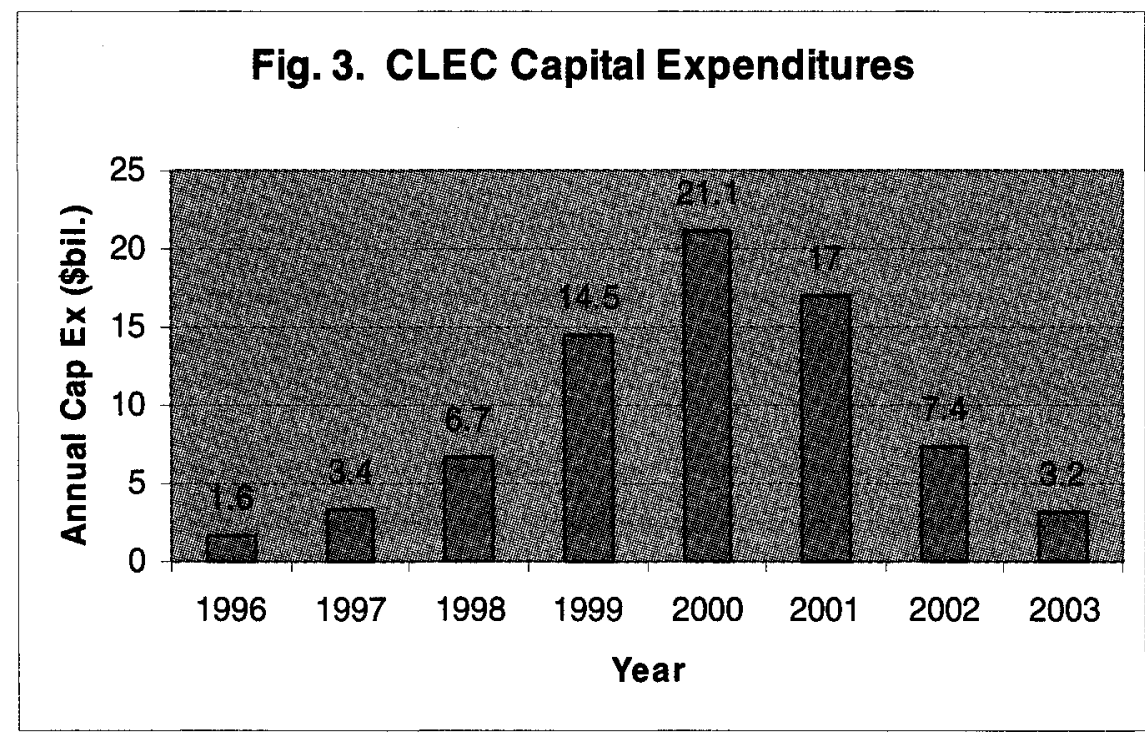

While CLEC investment was effectively disappearing, ILEC investment was rapidly declining. (See Figure 4.) While the postbubble direction is, as in other communications sector segments, downward, ILEC investment in 2003 was substantially below the 1996 level in nominal dollars. Capital expenditures by Regional Bell Operating Companies ("RBOCs"), about $\$ 22$ billion in 1996 , fell to about $\$ 17$ billion in 2003; adjusting by the Consumer Price Index, this constitutes a real decline of approximately $34 \%$.

49. The data in this subsection are taken from the ALTS Annual Report (2004) (on file with the Author) unless otherwise noted.

50. Id. at 18 (on file with the Author).

51. See Hazlett \& Havenner, supra note 2. 


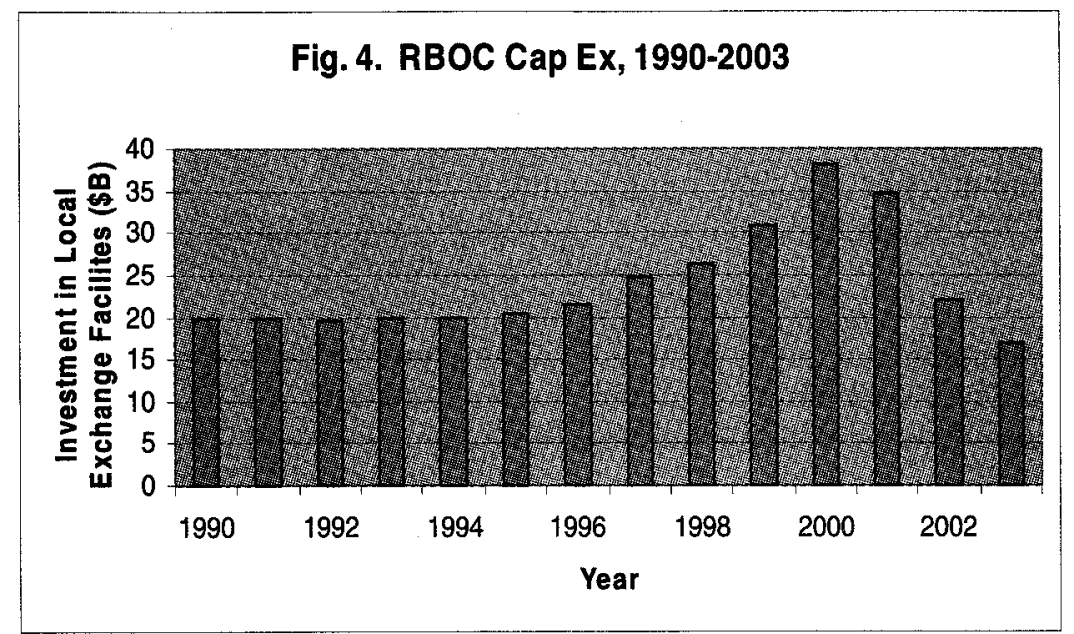

The fall in RBOC spending, then, does not appear to constitute simply a post-bubble adjustment. By 2003 , the annual investment flow had fallen to just $13.5 \%$ of revenues. (See Figure 5 , infra.) This appears to indicate network disinvestment, as industry analysts believe that a level of capital expenditure between $15-20 \%$ is necessary to simply maintain the capital stock. Morgan Stanley cites the experience of Ameritech, which reduced its capital expenditure to sales ratio to $13.7 \%$ in 1994 and 1995. "Service quality complaints filed with state regulatory authorities ramped significantly from 15 per 1 million access lines in 1994 to 1,044 per million in 2000 by the time the [acquisition by SBC] was closed."

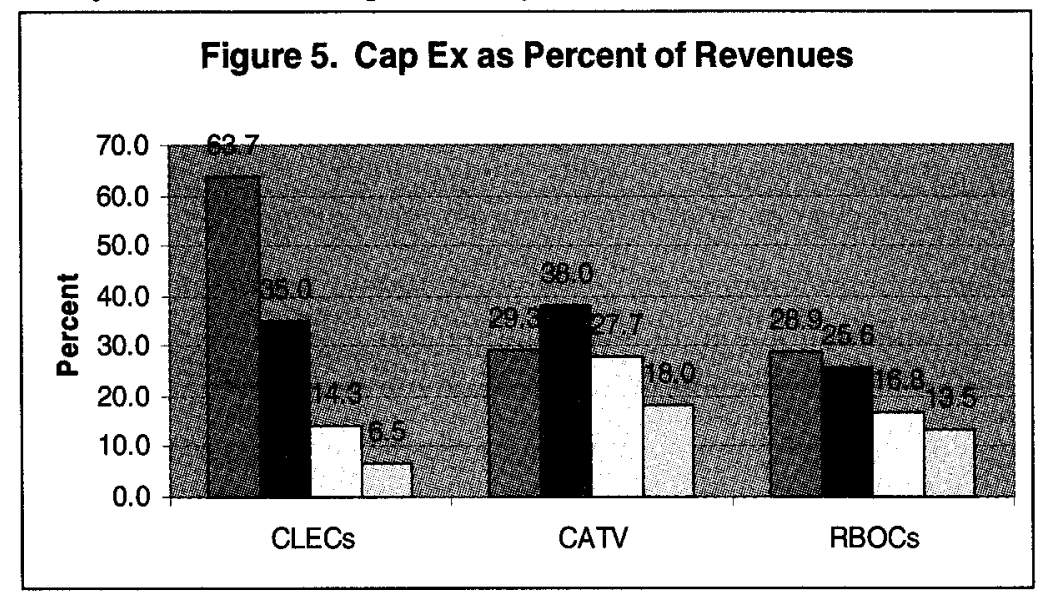

Source: New Paradigm Resources Group, in ALTS Annual Report (July 2004), slide 11.

52. Morgan Stanley, Wireline Telecom Services Trend Tracker: Nowhere to HIDE 52 (Mar. 3, 2003) (on file with the Author) [hereinafter TREND TRACKER]. 


\section{B. Telecommunications Regulation and the Investment Decline}

Financial analysts have repeatedly found that one important factor making telecommunications investments uneconomic, for both incumbent and competing carriers, is the overhang produced by network sharing mandates. The prospect that UNE-P line growth will ramp up, spurred by low, regulated wholesale terms, offers a disincentive to the creation of the substitute product-irreversible capital infrastructure.

A consensus of industry and financial analysts formed around the view that the U.S. approach to network sharing rules deterred investment. Analysts characterized UNE-P as a negative for both RBOC investors and the entire telecommunications industry. ${ }^{53}$ Analysts further noted that decreasing investment was rational for RBOCs, and hence positive for carrier shareholders. One "bright spot" identified by the investment community during the first quarter of 2003 - the height of the UNE-P line growth boom - was that "practically every telco reported capex well below our expectations." 54 One firm noted that with SBC's capital expenditure to revenue ratio at $9 \%$, there was little room for further cuts, while Bell South and Qwest "still have some room to cut" at $11-12 \%$, respectively, and Verizon at $15 \%$ "is likely best positioned to cut." $"$ As RBOC capital spending fell below maintenance levels, financial analysts hoped to see even deeper cuts. ${ }^{56}$ Morgan Stanley wrote that "[a]s the Bells approach

53. Precursor GrP., FCC DeCision ACCElerates Dis-INVESTMENT AND ShIFTS EQUIPMENT DEMAND (Mar. 4, 2003).

How the FCC Decision Depresses Overall Equipment Demand. Precursor believes the FCC's decision to invigorate/extend UNE-P resale competition will likely pressure core telecom equipment spending.... (1) Increasing profit pressure forces Bell capex cuts. ... (2) Enables AT\&T and WorldCom to cut current capex to fund UNE-P marketing. Preserving UNE-P for at least four years and making it available to more of the small business market encourages AT\&T and WorldCom to swap capex for more UNE-P marketing in order to improve cash flow and profitability short-term. (3) Increases capital investment risk and uncertainty. ... (4) Increases necessity of Bell-LD consolidation, reducing capex spending. Given that the government is artificially forcing down local profits, consolidation to achieve cost savings may be the only way to preserve some Bell shareholder value.

ld. (emphasis omitted) (on file with the Author). "The FCC ... increased its anti-investment bias by favoring resellers over infrastructure owners and equipment suppliers." SCOTT Cleland, Precursor Grp., Precursor Returning to Negative Telecom Outlook As FCC INVIGORATES UNE-P (Feb. 24, 2003) (emphasis omitted) (on file with the Author).

54. MERRILL LYNCH, ILEC SCORECARD 2 (May 15, 2003) (on file with the Author).

55. Precursor GrP.,'Telecom Disconnect': QualtTy of Bell Free Cash Flow WORSENING (July 21, 2003) (on file with the Author).

56. Fulcrum Global Partners, Wireline Communications: Thoughts on FCC ORDER (Feb. 25, 2003).

[W] would not be terribly surprised to see additional cuts from our nation's largest carriers, as they react to this current FCC order. If these companies are charged with the fiduciary responsibility of the underlying shareholders, at some 
spending of ... mid-teens percentage of sales levels, we do not believe that we have yet witnessed a bottoming of capex. If conditions worsen and UNE-P persists, we would expect more capex cuts across the board."

Figure 6. Net Capital Stock of Communications Networks

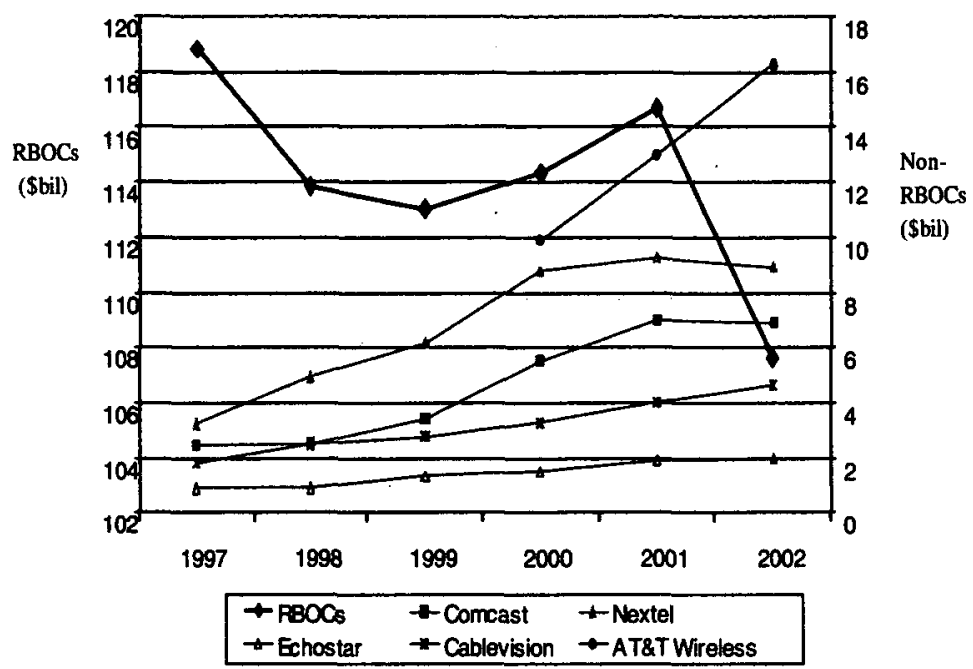

Sources: Company 10-Ks.

point it will be more responsible for the companies to begin returning cash flows to shareholders in the form of large dividends or share buy backs, rather than deploying capital into the network to generate negative returns for equity and debt holders.

Id. (on file with the Author).

57. TREND TRACKER, supra note 52. 
The post-Internet financial bust does not explain current trends. The net capital stock owned by RBOCs was flat in the boom period of the late 1990 s, and then declined sharply from those levels. In contrast, other U.S. communications industries-such as wireless and cable-expanded their net capital stock at a high rate during the boom, and then reduced investment growth while maintaining capital infrastructure.

Figure 6 shows the net capital stock for leading pure play firms in wireless telephony, cable TV, and satellite TV, along with the RBOCs. ${ }^{58}$ Although the growth of capital stock in these other sectors has flattened, in contrast to the wireline sector, capital stock is not declining. This is true despite the fact that these sectors all experienced rapid expansion in the boom phase of the current cycle, while the BOCs did not.

Similarly, the cable industry did not reduce its capital stock despite having largely completed a major upgrade of its facilities nationwide. Even after building out two-way digital infrastructure for the delivery of digital video and cable modem service, investment remained at historically high levels. As Figure 7 shows, cable capital expenditures were more than double RBOCs' in 2002, standardizing on the respective levels of 1996 investment. ${ }^{59}$ Similarly, investors spent substantial sums to create satellite distribution platforms in the $1990 \mathrm{~s}$, but then continued to increase net capital stock post-bubble. (See Figure 7.)

58. These firms are AT\&T Wireless and Nextel (wireless telephony), Comcast and Cablevision (cable TV), and EchoStar (satellite TV). By focusing on pure plays, it is possible to see the financial picture across different industries. Firms serving multiple markets typically do not break out capital assets for their component parts, making aggregate company data less useful in revealing industry trends.

59. While UNE-P deterred telephony upgrades, the cable industry has successfully opposed "open access" mandates for video and cable modem service, the two markets in which local cable operators are dominant and which provide the vast majority of industry revenues. The legal question surrounding regulation of cable modem service was resolved by the U.S. Supreme Court in National Cable \& Telecommunications Assoc. v. Brand $X$ Internet Services, 345 F.3d 1120 (2005). 
FIGURE 7. NORMALIZED RBOC AND CABLE TV SYSTEM CAPITAL $\operatorname{STOCK}(1996=1)$

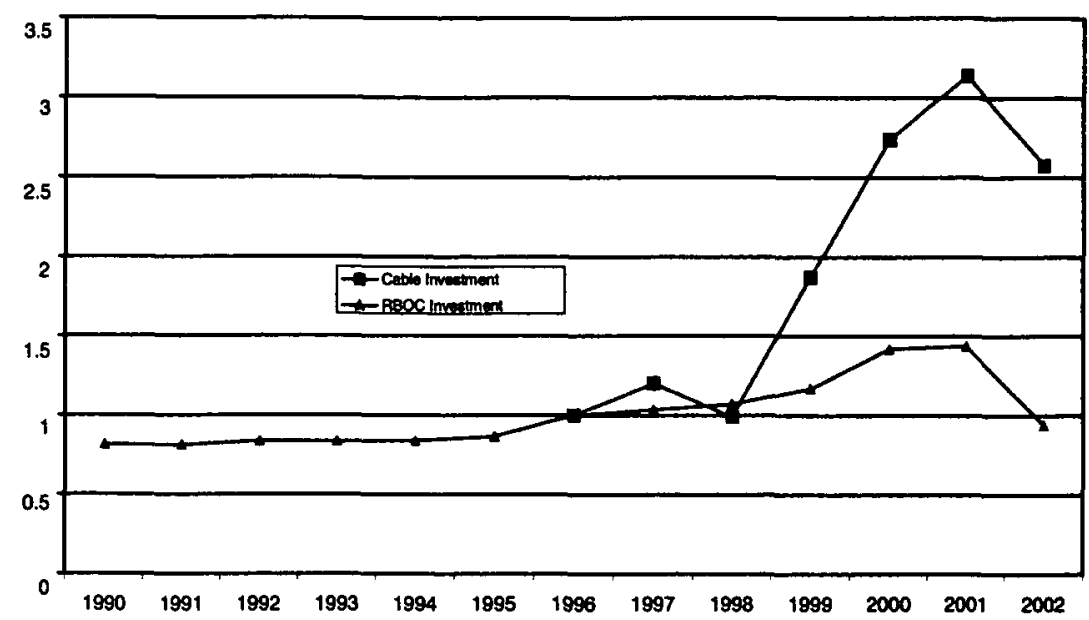

\section{Regulated Resale as a Business Model}

Market and financial analysts reached a broad consensus that the resale opportunities put into place by regulation suppress incumbents' and competitors' investments in network facilities. The generous profit opportunity seemingly awarded new competitors disappears in retail discounts and customer acquisition costs. ${ }^{60}$ Despite serving more than 4 million subscribers via UNE-P lines, AT\&T's entire local residential business was found essentially worthless in a June 2004 valuation by Legg Mason. Analysts concluded that "the durability of UNE-P remains relatively immaterial to long-term sector valuations “61

The unprofitability of the resale option for entrants undermines the logic of network sharing rules. These mandates arguably offered complementary inputs to facilities-based entry, increasing the chance of financial success. The path chosen by the largest CLECs, AT\&T and MCI, focused almost entirely on resale, a business model that ultimately proved unremunerative even when wholesale prices were sufficiently low as to encourage entry. This, combined with an observed crowding out of facilities-based entry, offers further evidence rejecting the stepping stone theory.

60. See Hazlett \& Havenner, supra note 2, at 442.

61. Legg Mason, Bush administration Declines to BaCK FCC Appeal of D.C. Circuit's Pro-Bell Triennial Review Ruling (June 9, 2004) (one file with the Author). See also AT\&T, SEC FORM 10-Q 26, 28 (June 30, 2004) (one file with the Author). 


\section{Revealed Policy Preferences of Equipment Suppliers}

Also informative are the views of telecommunications equipment manufacturers. Companies such as Intel, Nortel, and Cisco sell key network components to a wide array of customers. The firms are indifferent to transfers between telephone companies, but desire healthy economic conditions that give investors incentives to build networks and upgrade existing facilities. Manufacturers particularly gain with the construction of advanced networks, such as those supplying broadband services.

These firms have repeatedly argued that compulsory network sharing can be dangerous for investment and should be applied lightly if at all. A good example appears in comments Nortel filed with the FCC in 2002:

Telecom service providers will not invest in infrastructure when regulatory burdens adversely affect the viability of business cases and shareholder return on investment. Without such investment, the equipment suppliers and solutions providers that create innovation will be unable to sustain their research-and-development efforts. The present unbundling and pricing rules result in disincentives to investment on both sides of the issue-for ILECs because they're required to unbundle and for CLECs because they have much to gain by waiting for ILECs to construct facilities instead of building their own.

A Vicious Cycle. Like every other business, carriers need the freedom to earn a market-based return on their investment. Unreasonably low, regulated pricing of network elements by definition prevents a market-based rate of return, inevitably resulting in less infrastructure investment. This, in turn, leads to less spending with technology suppliers, which leads to less money available for technology companies to invest in developing new technology, resulting in a negative impact on innovation. Productivity and the overall economy are adversely affected. This is the vicious cycle we are facing today. This cycle must be interrupted. ${ }^{62}$

That the demand for telecommunications equipment is a negative function of the regulatory sharing mandates is widely shared in the manufacturing sector. Industry analysts at the Gartner Group analyzed the impact of November 2004 rules announced by the FCC that will exempt fiber-to-the-curb deployments built by ILECs or others from unbundling obligations. This was not only seen as a positive development for RBOCs, who would own such infrastructure, but for sellers of fiber-optic systems. The Gartner analysis explicitly forecasts higher sales of advanced fiber network technology due to the decision not to regulate. (See Figure 8.)

62. Review of Section 251 Unbundling Obligations of Incumbent Local Exchange Carriers, Ex parte Comment of Nortel Networks, CC Dkt No. 01-338, (2002) (one file with the Author). 
Figure 8. Gartner Fiber-Optic Technology Sales Forecast ${ }^{63}$

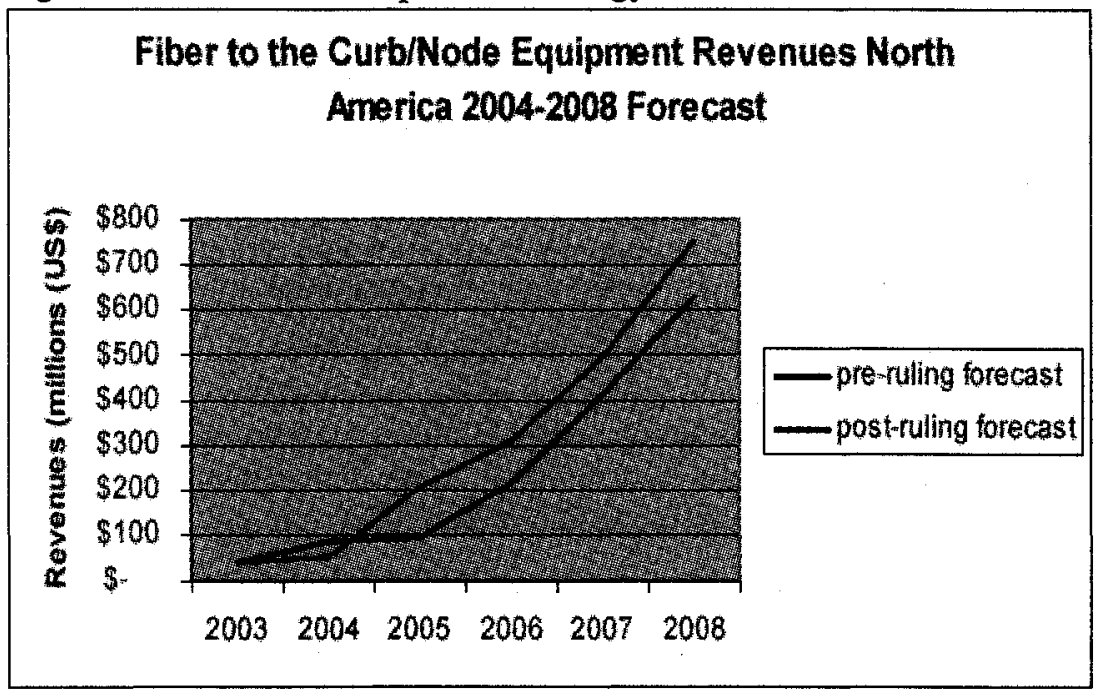

\section{WIRELESS NETWORKS}

\section{A. Fixed-to-Mobile Substitution}

Wireless phones are increasingly serving as substitutes for fixed line telephony, particularly in the residential market. An international perspective clearly reveals that extensive substitution is possible. According to one survey of the European Union, $15 \%$ of households are now without any fixed line. This proportion reaches 33\% in Finland and Portugal. ${ }^{64}$ Other recent surveys set the Finnish fixed line penetration even lower. (See Table 1.) The trend toward substitutability is unmistakable.

63. Gartner GrP., ONe Gigabit OR Bust Roundtable (Nov. 15, 2004) (on file with the Author).

64. The cited statistic excludes recent entrants to the EU, including those in Eastern Europe. Europa, Information Society, Household Communications in the EU: Mobile Penetration Catches Up with Fixed Lines, and Broadband Connections Double, http://europa.eu.int/information_society/newsroom/cf/itemlongdetail.cfm?item_id=1347 (last visited Apt. 12, 2006). 


\begin{tabular}{|l|l|l|l|l|c|}
\hline \multicolumn{6}{|c|}{ Table 1. Fixed to Wireless Substitution in Five EU Countries } \\
\hline & Finland & Italy & Norway & Sweden & Germany \\
\hline $\begin{array}{l}\text { mobile } \\
\text { penetration }\end{array}$ & $91 \%$ & $97 \%$ & $85 \%$ & $97 \%$ & $83 \%$ \\
\hline $\begin{array}{l}\text { Res Fixed } \\
\text { Lines per } \\
\begin{array}{l}100 \\
\text { Households }\end{array}\end{array}$ & 64 & 83 & 86 & 99 & 80 \\
\hline
\end{tabular}

Source: NORTHSTREAM, FIXED-TO-MOBILE SUBSTITUTION IN EUROPE, (SEPT. 2004), http://72.14.207.104/search?q=cache:sAAz3w2oF-

EJ:www.incodewireless.com/media/whitepapers/2004/Irreversible_fixedto-mobile_substitution_in_Europe.pdf+fixed+to+mobile+substitution+ europe $\& \mathrm{hl}=\mathrm{en} \& \mathrm{gl}=\mathrm{us} \& \mathrm{ct}=\mathrm{clnk} \& \mathrm{~cd}=4$.

In the United States, substitution is most evident in long-distance traffic. Wireless users, offered buckets of domestic minutes under digital one-rate plans-first introduced by AT\&T Wireless in May 1998increasingly use mobile phones to make their long-distance calls. While relatively few households have cut the cord, minutes of use are shifting from fixed to mobile.

This emerging alternative to fixed-line service is obvious and provokes an examination of federal policies. Regulation to open local markets pursuant to the 1996 Act has ignored fixed-to-mobile substitution, viewing wireless as a separate market. This too-narrow approach has led to difficulties within the telecommunications unbundling regime and to policy failure in spectrum allocation. The FCC has inadequately permitted mobile phone networks to develop either voice or broadband services due to artificial bandwidth constraints applied by government regulation.

\section{B. Spectrum Allocation}

The U.S. market does, it should be noted, exhibit a fairly high degree of competition between mobile carriers, a rivalry that extends to technology choice. Unlike in many other countries, U.S. regulators have, since 1988, permitted wireless operators to select their own technical formats. This has led to the development of three competing systems: Global System for Mobile Communications ("GSM") used by the Cingular and T-Mobile networks; Code Division Multiple Access ("CDMA") used by Verizon Wireless and Sprint-Nextel; and Integrated Digital Enhanced Network 
("iDEN") used by the Nextel network (which was acquired by Sprint, to form Sprint-Nextel, in 2005).

U.S. policy over the past fifteen years, however, has been relatively unresponsive in two other crucial dimensions. First, serious lags have been incurred in issuing licenses to operators. While EU countries received $2 \mathrm{G}$ ("second generation") digital cellular licenses 1989-1992, American licenses were issued beginning in 1995 and, due to confusion over bidding preferences extended small businesses, the process took a decade to complete. Long before U.S. $2 \mathrm{G}$ licenses were fully distributed, EU countries had assigned $3 \mathrm{G}$ licenses (mostly in 2000 and 2001). ${ }^{65}$

Fig. 9 Gartner Fiber Optic Technology Sales Forecast

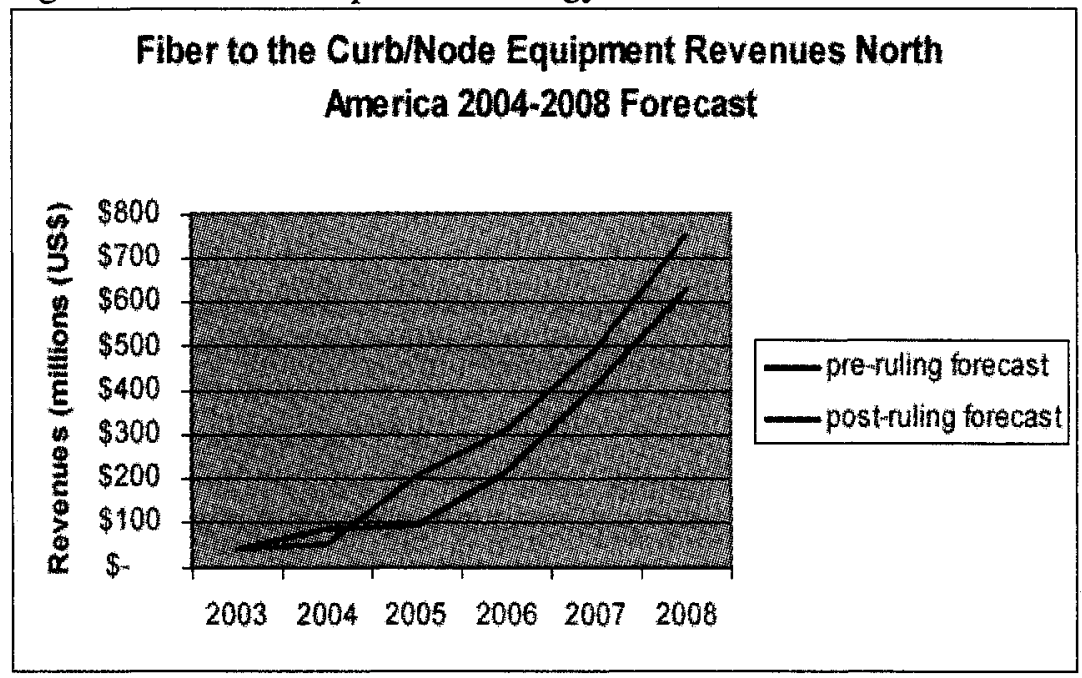

The result is that U.S. wireless operators utilize only about $190 \mathrm{MHz}$ of bandwidth, approximately $100 \mathrm{MHz}$ less than countries of comparable income levels. (See Figure 9.) This regulation-imposed constraintabundant underutilized spectrum could be allocated to licenses and sold at auction to competing bidders ${ }^{66}$ - costs the U.S. economy substantial sums

65. An FCC auction scheduled to commence June 2006 is the earliest that such licenses will be awarded in the U.S.

66. Two FCC policy experts have identified $438 \mathrm{MHz}$ of prime spectrum (under 3 $\mathrm{GHz}$ ) that could be reallocated for flexible use, allowing licensees to provide mobile telephony, broadband, or other services. See Evan Kwerel \& John Williams, A Proposal for a Rapid Transition to Market Allocation of Spectrum (FCC Office of Plans and Policy, Working Paper No. 38, 2002), available at http://hraunfoss.fcc.gov/edocs_public/attach match/DOC-228552A1.pdf. 
in lost consumer surplus. More directly relevant to the analysis of local telephone competition, allocated spectrum would lower per-minute rates for wireless phone use and expand wireless broadband connectivity. These networks, already provided by multiple competitors, offer close substitutes to services provided by ILECs. By misallocating a vital input, regulators greatly hinder telecommunications policy goals.

Additional spectrum, with rights assigned exclusively and with liberal usage permitted, is extremely valuable at the margin. Econometric analysis of wireless markets in twenty-nine countries shows that the relationship between spectrum allocation and retail prices is strongly negative. ${ }^{67}$

Countries with more allocated spectrum enjoyed substantially lower prices for mobile phone service, and the difference is statistically significant. Simulations show that the average price per minute of use, estimated in the model to be about $\$ 0.11$ in 2003 , would fall to about $\$ 0.085$ if an additional $80 \mathrm{MHz}$ were allocated and to under $\$ 0.06$ per minute were $200 \mathrm{MHz}$ made available. Demand is found to be elastic, meaning that the minutes of use of mobile telephone service would rise by a larger percentage increase than the percentage decrease in prices. (See Table 2.)

These changes would produce huge social benefits on their own: some $\$ 32$ billion in additional consumer surplus-the increase in consumer wellbeing over and above what the service costs them-is generated per year with another $80 \mathrm{MHz}$ allocated to wireless telephony. And by reducing prices for mobile telephony, intermodal competition with fixed-line networks is stimulated.

67. See Thomas W. Hazlett \& Roberto MuÑoz, AEI-Brookings JoINT CENTER For Regulatory Studies, A Welfare analysis of Spectrum Allocation Policies 4-5 (2004), http://www.aei-brookings.org/admin/authorpdfs/page.php?id=1024. 


\begin{tabular}{|l|c|c|c|c|c|c|c|}
\hline \multicolumn{8}{|c|}{$\begin{array}{l}\text { Table 2. Additional Consumer Surplus in Wireless } \\
\text { Telephony from Additional Spectrum Availability }\end{array}$} \\
\cline { 3 - 8 } & \multicolumn{3}{|c|}{ An Additional Spectrum Allotment of: } \\
\hline & $\begin{array}{l}\text { Initial } \\
\text { Value }\end{array}$ & $\begin{array}{l}\text { Final } \\
\text { Value }\end{array}$ & $\% \Delta$ & $\begin{array}{l}\text { Final } \\
\text { Value }\end{array}$ & $\% \Delta$ & $\begin{array}{l}\text { Final } \\
\text { Value }\end{array}$ & $\% \Delta$ \\
\hline $\begin{array}{l}\text { Average } \\
\text { Price/Min. }\end{array}$ & 0.112 & 0.084 & -25 & 0.069 & -38.39 & 0.056 & -50 \\
\hline $\begin{array}{l}\text { Min. of } \\
\text { Use/Month } \\
\text { (mil.) }\end{array}$ & 78,340 & 115,098 & 46.92 & 135,763 & 73.3 & 153,038 & 95.35 \\
\hline $\begin{array}{l}\text { Consumer } \\
\text { (mil.) }\end{array}$ & Surplus 4 & $\$ 31,850$ & & & & & \\
\hline
\end{tabular}

The value of licenses sold at auction is an additional source of social gain, but a relatively minor part of the welfare generated by incremental spectrum allocations. Firms bid for licenses on the basis of expected profits, which are likely to be at least an order of magnitude less than consumer surplus. Moreover, the more bandwidth mobile competitors can use, the less a given license will be worth at auction, precisely because competitive pressures intensify as additional capacity is available to service providers.

Additional allocations of licensed, flexible use spectrum also advance deployment of wireless broadband networks, broadening the cable modem versus DSL rivalry. Each national wireless network would offer high-speed Internet access were spectrum more widely available. Indeed, recent mergers have made this clear. After acquiring AT\&T Wireless, Cingular announced that it would be upgrading its network to provide $400-700 \mathrm{kbps}$ Univeral Mobile Telecommunications Service ("UMTS") service and attributed its new strategy directly to the fact that the merger gave it the bandwidth to offer broadband data in addition to voice and narrowband data. ${ }^{68}$ Both Sprint, having acquired Nextel, and Verizon, having acquired numerous Nextwave licenses, are building national EV-DO networks, providing 300-700 kbps data service. ${ }^{69}$ T-Mobile, left without spectrum

68. Matt Richtel, Cingular to Upgrade Data Network, N.Y. TIMES, Dec. 1, 2004, http://select.nytimes.com/gst/abstract.html?res=FA0E1EFB3A5A0C728CDDAB0994DC40 4482 (requires purchase).

69. Kevin Fitchard, CTIA: Sprint building out 3G, lays out revision A plans, TELEPHONY ONLINE (Mar. 31, 2006), http://telephonyonline.com/home/news/sprint_3g revision_033106/. 
rights to acquire, has declared that it has been unable to upgrade its network to provide broadband service due to its spectrum constraint. ${ }^{70} \mathrm{~A}$ recent industry web site summarized T-Mobile's data strategy: "Continue with EDGE [narrowband data] rollout until enough spectrum is found for W-CDMA [broadband] technology.,"71

Not only would spectrum policies that made additional bandwidth available for the development of broadband networks lead existing cellphone carriers to offer expanded service, it would clear a path for additional entrants. With licenses in the $2.5 \mathrm{GHz}$ band, Clearwire is attempting to create a nationwide wireless broadband network. Backed by cellular pioneer Craig McCaw, service is currently provided in Jacksonville, Florida; Daytona, Florida; St. Cloud, Minnesota; and Abilene, Texas along with several others, providing wireless Internet access at maximum download speeds of $768 \mathrm{kbps}$ to $1.5 \mathrm{Mbps}^{72}$ Spectrum constraints are impeding Clearwire's rollout. The formation of other platforms is also deterred, including Aloha Networks' $700 \mathrm{MHz}$ service. ${ }^{73}$ In countries that have made spectrum more available to the market, wireless broadband networks are already being built. South Korea has over 12 million EV-DO subscribers, using CDMA wireless phone networks to transmit audio and video. ${ }^{74}$ Korea's three CDMA phone networks are allocated a total of $230 \mathrm{MHz}$, making it economical to provide both voice and high-speed data. An additional $100 \mathrm{MHz}$ in the $2.3 \mathrm{GHz}$ to $2.4 \mathrm{GHz}$ band has been allocated for Wi-Bro, a Korean version of WiMax (wireless broadband). ${ }^{75}$

In Australia, where a more liberal spectrum regulatory policy is in place, ${ }^{76}$ multiple wireless broadband alternatives compete. Sydney " "has become the world's leading market showcase for wireless data services,'

70. Dan Meyer, Verizon expands EV-DO, Cingular says it's under no pressure to match speed, RCR WIRELESS NEws, July 4, 2005, http://www.highbeam.com/doc/1G1:

$133835239 /$ Verizon+expands+EVDO,+Cingular+says+its+under+no+pressure+to+match+s peed R (News).html?refid=SEO (requires purchase).

71. Daily Wireless, The $700 \mathrm{Mhz}$ Club, http://dailywireless.org/modules.php?name= News\&file=article\&sid=3714 (last visited Apr. 13, 2006).

72. Clearwire, Service Plans, http://www.clearwire.com/store/service_plans.php (last visited Apr. 14, 2006).

73. Daily Wireless, supra note 71.

74. IP Inferno, Samsung Wimax Presentation, Oct. 26, 2005, http://ipinferno.blog spot.com/2005_10_01_ipinferno_archive.html.

75. Mike Clendenin, South Korea Preps Deployment of WiMax Variant, EE TIMES ONLINE, Jan. 21, 2005, http://www.eetimes.com/news/latest/showArticle.jhtml?articleID= 57702772.

76. See Thomas W. Hazlett, Property Rights and Wireless License Values 12 (AEIBrookings Joint Center for Regulatory Studies, Working Paper No. 04-08, 2004), available at http://aei-brookings.org/admin/authorpdfs/page.php?id=771. 
says Robin Simpson, an analyst with U.S. technology research firm Gartner in Australia. . . . [A] reason wireless broadband is taking off here: The government sold off radio spectrum for such services relatively cheaply."77 Both Unwired Australia and Personal Broadband offer service with the latter expanding coverage to Melbourne. Using technology from Arraycomm called iBurst, Personal Broadband offers mobile users $1 \mathrm{Mbps}$ service for $\$ 40$ per month with desk top usage priced at $\$ 28 .^{78}$ Arraycomm, a U.S. company, has attempted for several years to deploy its service in the United States, but has been unable to obtain the necessary licenses.

\section{State Regulation of Cell-Phone Rates}

Additional evidence relevant to ongoing policy analysis is gleaned from the experience with cellular telephone rate controls in the U.S. Wireless telephone charges were regulated in California, New York, Arizona, and several other states until federal preemption in August 1994. During this time, the industry was highly concentrated, with just two firms operating in each local market, as dictated by federal licensing policy. Market power was clearly in evidence, and retail prices were substantially higher than competitive levels despite rate regulation. ${ }^{79}$

When federal law was set to eliminate this state-level rate regulation, many state public utility commissions requested exemptions, arguing that without regulation consumers would be charged higher prices. The FCC denied all such requests, and cellular phone rates were deregulated on August 10, 1994.

During the $1989-1993$ period, ${ }^{80}$ when states were allowed to regulate rates, charges declined only slightly. (See Figure 10.) In contrast, with facilities-based entry ${ }^{81}$ and the consolidation of local and regional systems into nationwide networks, market forces drove substantial rate reductions. The magnitude of those attributable to competition relative to what state regulators were able to achieve ${ }^{82}$ is suggested by projecting the trend for

77. Rebecca Buckman, Unbound Down Under, WALL ST. J., Feb. 17, 2005, at A1, available at http://www.freepress.net/news/print.php?id=6786.

78. Stephen Withers, iBurst bursts into Melbourne, ZDNET AUSTRALIA, Feb. 22, 2005 , http://www.arraycomm.com/docs/20050222ZDNetiBurstburstsintoMelbourne.pdf.

79. See California Public Utilities Commission, Investigation on the Commission's Own Motion into Mobile Telephone Service and Wireless Communications, Decision 94-08022 (Aug. 3, 1994).

80. This uses the earliest price data found, that for 1989.

81. The licensing of personal communications services began in 1995. The award of two $30 \mathrm{MHz}$ licenses (PCS A and PCS B) was achieved fairly expeditiously, meaning that two new entrants (per market) were authorized across the U.S. within months of the close of the A-B auction in March 1995.

82. It is true that a minority of states claimed to fully regulate cellular rates, but all states had the option of doing so. This allows one to think of the pre-1994 regime as being 
wireless rates through 2002. With federal deregulation, the actual price fell to $\$ 0.12$ per minute, while the projected 2002 rate under the most favorable (i.e., declining) linear pre-deregulation trend, which connects 1992 and $1994,{ }^{83}$ is about $\$ 0.33$ per minute $-175 \%$ higher. The deregulated but more competitive environment dramatically outperforms, underscoring the importance of public policies that produce facilities-based entry.

Figure 10. CEllular TElePHONE RATES, 1989-2002

National Average Price Per Minute of Use ${ }^{84}$

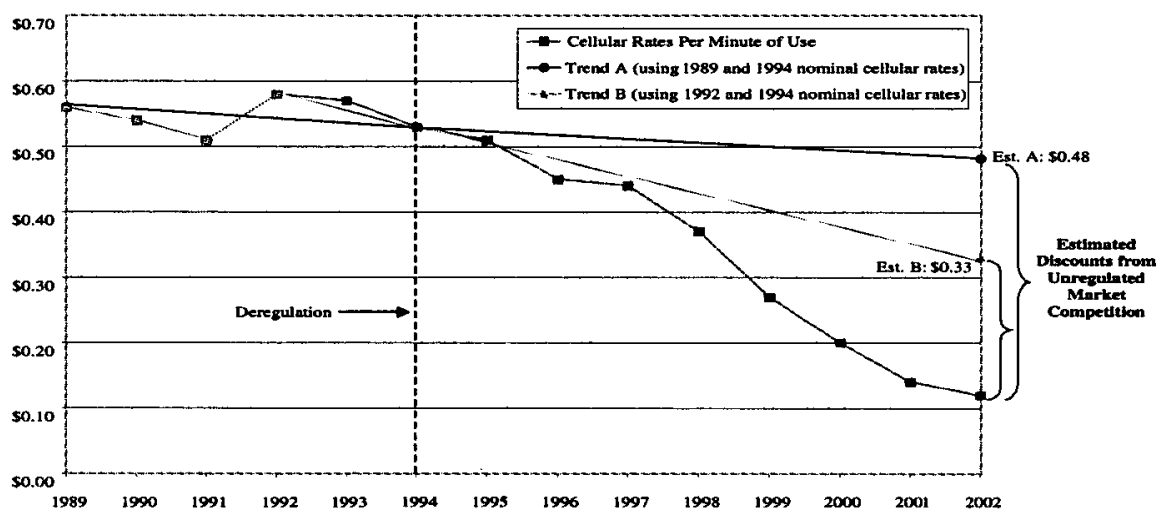

\section{Resellers in an Unregulated Market}

A striking development in mobile phone markets is the emergence of an active wholesale market. The mechanism that was unsuccessfully imposed by telecommunications regulators attempting to jumpstart competitive fixed-line networks has been created by the reverse process in wireless: as competitive networks became established they naturally looked to expand their business by partnering with resellers.

At least twenty such resellers compete. Some have become substantial: TracFone serves over 3.5 million customers, ${ }^{85}$ and Virgin Mobile USA

one of state regulation. Consistent with this is evidence that states with rate regulation had rates no lower than unregulated states. See Thomas W. Hazlett, Is Federal Preemption Efficient in Cellular Phone Regulation?, 56 FED. COMM. L.J. 155, 214 (2003), available at http://www.law.indiana.edu/fclj/pubs/v56/no1/hazlett.pdf.

83. Calibrating the price trend by using the 1989-94 interval produces far larger rate differentials in 2002. Ending in 1993, the last complete year of state-level rate regulation, produces an upward slope for the price trend.

84. Estimate A: 2002 cellular rate (price) derived using 1989-94 trend. Estimate B: Rate derived using 1992-94 trend. See CTIA, WIRELESS INDUSTRY INDICES, SEMIANINUAL SURVEY (2005), http://files.ctia.org/pdf/CTIAYearend2004Survey.pdf. 
over 3 million. ${ }^{86}$ About twenty million mobile users, ten percent of all wireless subscribers, will be served by MVNOs in $2006 .{ }^{87}$ MVNOs market retail phone service with actual networks provided by Sprint, Verizon, Cingular, and various regional carriers.

The MVNO business model has become standardized, creating a platform hospitable to differentiated products. One industry entrepreneur, EarthLink founder Sky Dayton, has launched a $\$ 440$ million venture to offer state-of-the-art high-speed Internet-connected devices. Aimed at early adopters of advanced wireless technologies, he is partnering with (Korean wireless operator) SK and EarthLink, reselling wireless broadband provided by EV-DO networks under the brand name Helio. As reported by BUSINESS2.0:

Here's the cool part, from an investor's point of view: SK-EarthLink will try to reach that goal without spending a dime developing its own infrastructure. Instead, the upstart carrier will rely on Sprint and Verizon Wireless to provide the backbone for its wireless offerings. SK-EarthLink will function as a mobile virtual network operator (MVNO), essentially renting access to each network. It will pay the carriers a per-minute fee each time one of its customers makes a phone call or streams a video broadcast. ${ }^{88}$

The insurmountable hurdles that appear with forced marriages evaporate when relationships are forged from mutual advantage. Hence, the barriers afforded by investments in irreversible capital are replaced by competitive wholesale pricing, which, in turn, enables innovative retail competition. The arrival of physical networks streamlined entry into the wholesale market, not vice versa.

\section{CONCLUSION}

The regulatory response to the 1996 Act focused on creating competitive networks from the inside out. By allowing multiple retail competitors to share the existing fixed-line phone system in each territory, regulators hoped to see the emergence of new network build-out over time. The strategy was ambitious in its legal, political, and economic requirements, needing delicate balance. Terms for wholesale network access that were too generous to entrants' sharing facilities would raise the

85. TracFone, About Us, http://www.tracfone.com/about.jsp?task=about\&current View=asurion (last visited Apr. 14, 2006).

86. Pieter de Villiers, Virgin Mobile USA Hits 3 Million Subscribers, Wireless World Forum, Feb, 10, 2005, http://www.w2forum.com/item/virgin_mobile_usa_hits_3_mn_ subscribers.

87. Stanley Rothman, Sending the Brand into the Wireless World, N.Y. Times, May 3, 2006, http://www.nytimes.com/2006/05/03/technology/techspecial3/03fun.html?ex= 1147838400 \&en $=348370573560336 \mathrm{~b} \& \mathrm{ei}=5070$ (requires subscription).

88. Maier, supra note 27. 
relative cost of new infrastructure investment and deter it; terms that were insufficiently generous would stimulate little entry.

We have seen marketplace events play out in the decade since passage of the 1996 Act. The network sharing regime, while encouraging growth in retail rivalry in the $2000-04$ period, did not provide a stepping stone to facilities-based competition. Instead, the emergence of fast-growing UNE$P$ resale crowded out the development of rival infrastructure, leading investors to withdraw capital from the sector. The dearth of network investment was seen in the deployments of both incumbent and competitive local phone carriers.

After eight years of regulatory process, the regime was found to be in violation of the very law that had inspired it. Moving for the third and decisive time in March 2004, the federal courts declared that the network sharing rules devised by the FCC had failed the balancing test required in the 1996 Act. Unbundled network elements were mandated too widely, without regard for the disincentives such wholesale access would likely have in the construction of advanced systems and competitive networks. This undermined, and violated, the stated goals of the law.

The legal collapse of the network sharing regime has coincided with independent marketplace developments fortuitously introducing the competitive structures public policy aimed to achieve. Rivalrous platforms have arisen to encroach on markets served by incumbent carriers, outside in. Wireless telephony, with over 175 million American subscribers, is moving ever closer to fixed-line service in product space with the added advantage of mobility. Cable TV systems provide a nationwide network parallel to that provided by local exchange carriers. In the wake of deregulation, one half of households can subscribe to POTS via the local cable operator, and virtually any household can use VoIP-without a "phone company"-by subscribing to cable modem service, where telephony is simply an application riding on broadband networks. Reduced network sharing obligations encourage deployment of VoIP, eliminating the business risks that slowed the growth of cable telephony.

Additional pro-competitive policies would assist the emergence of new networks and the deployment of advanced communications technologies. Chief among these are more liberal spectrum allocation. U.S. policy has imposed artificial constraints on the key inputs available to wireless service providers, raising the cost of mobile voice service, retarding its competitiveness. These policies also stymie the creation of wireless broadband networks as are today being deployed in countries with less restrictive policies. Removing these impediments to network formation would have been a superior course for policy makers in the years since the 1996 Act outlined a transition path from regulated monopoly to market competition. Now, with the mandatory network sharing regime proven 
unworkable and, ultimately, illegal, regulators ought to embrace this policy alternative as if it were their first choice. 
